\title{
Judges, Critics, and the Realist Tradition
}

\author{
Hans A. Linde ${ }^{\dagger}$
}

In reviewing contemporary criticism of the constitutional decisions of the Supreme Court during the tenure of Chief Justice Earl Warren, Judge J. Skelly Wright ${ }^{1}$ characterized as the "scholarly tradition" a way of thinking about constitutional law that he found exemplified by the early Oliver Wendell Holmes lectures, the Harvard Law Review's annual Supreme Court forewords, and particularly the recent writings of Professor Alexander Bickel and Professor Philip B. Kurland. ${ }^{2}$ The judge's critique of the critics raises the question whether the criteria of this "scholarly tradition" are the proper measure either of constitutional law or of the performance of the Supreme Court.

Characteristically, questions of constitutional law and questions of the role of the Supreme Court are generally treated as the same thing. This faithfully reflects the tradition of two generations of legal realism -the common core of tradition shared by most scholarship and most appellate judging today. The identity between the law in operation and the role of courts is a premise first year students absorb in such time-hallowed epigrams as Holmes's definition of law as a prophecy of what a court will do in fact, ${ }^{3}$ and Hughes's "the Constitution is what the judges say it is." 1 It is "the realist school of jurisprudence to which both sides of the alleged controversy over the Warren Court pretend to adhere" wrote Kurland, ${ }^{5}$ and Bickel devoted a brilliant opening chapter of The Supreme Court and the Idea of Progress to sketching the intellectual and political ascendancy of the "Progressive Realists" in constitutional law. ${ }^{6}$

But there is more to the scholarly tradition of legal realism than a facile derivation of law from the judicial function. Never a closely

\footnotetext{
$\dagger$ Professor of Law, University of Orcgon.

1. Wright, Professor Bickel, The Scholarly Tradition, and the Supreme Court, \&4 HARv. L. REv. 769 (1971).

2. Id. at 770. Judge Wright refers to the famous Holmes Lectures of Judge Learned Hand, THE BILL OF RIGHTS (1958) and Herbert Wechsler, Tou'ard Neutral Principles of Constitutional Law, 79 HARv. L. REv. I (1959); he excmpts from his strictures a number of scholars who have been sympathetic to the direction of the "Warren Court." Wright, supra note 1 . The focus of his attack is upon kurland and Bickel, particularly P. kur:land, Polmics, the Constitution and the WARBen Colrt (1969) [hercinafter cited as Polmics] and A. Bicken, The Suprese Court ANd the Ides of Procress (1970) [hercinafter cited as IDEA of Progress].

3. O. Holmes, The Common Law 68 (1963 ed.).

4. C. Hughes, The Suprease Colrt of the United States 120 (1928).

5. Politios 18-19.

6. IDEA of Progress, ch. 2.
} 
defined theory, "legal realism" invokes both a critic's stance in dcscribing the social reality of law and courts, and the forensic usc of "realist" premises. Realism began as a technique for the observation, description, and criticism of law in contrast to prevailing legal formal. ism; but in a country whose leading theorists about law have been men deeply engaged in its practical application, theories of description and theories of action would not be sharply distinguished. What began as a doctrine for critics was expected to become a doctrine also for judges.

A number of distinct demands are put to appellate courts in the name of realism, though not always by each individual critic. First and foremost, the realist canon assumes that an appellate decision of first impression has, or ought to have, a pragmatic social goal. New decisions are therefore to be assessed in instrumentalist terms. Are the postulated goals "really" desirable and attainable in the light of social reality, and will the chosen rule actually achieve them? Accordingly, judges are enjoined to decide questions of law with a realistic view of the factual setting that shapes the particular rule's objective and its practical operation. Kurland cites Holmes's dictum that "we must think things, not words, or at least we must translate our words into the facts for which they stand, if we are to keep to the real and the true," as the "primary teaching of the realist school of jurisprudence" shared by all sides in the debate over the Warren Court. ${ }^{7}$ Related to this is a demand for candor in judicial opinions. ${ }^{8}$ A decision should not only appear realistic to an observer, it should be derived from realist premises, and judges should give the "real" reasons supporting their judgments.

Apart from substance and style, a court-above all the United States Supreme Court-is expected to pursue institutional concerns, to keep a realistic eye on the probable effectiveness of its action, on the likelihood of its success, and on its own position as one institution among others. Thus it must worry that its judgments may remain abstract declarations that will be evaded "or worse yet, be repudiated," that its commands may not have the desired effect or even be obeyed, or that persistence in a course of principled decisions may endanger its institutional survival. ${ }^{9}$

"Success," in a word, is the unsurprising touchstone of the realist

7. PoLitics 18-19.

8. IDEA OF PROGREss 24. A recent statement of this claim, from Handler, The Supreme Court and the Anti-Trust Laws, 1 GA. L. REv. 339, at 355 (1967). "That one word-candorilluminates what modern legal education is all about. It is the distinctive feature of a mature jurisprudence," and again, "The great judicial craftsmen proceeded from the particular to the general ... ; they were slaves to neither logic nor history; they rcsponded to the pressure of the facts ...."

9. IDEA OF PROGRES 95, 96; Politics 19. 
critique. Judicial statecraft, in constitutional adjudication, is to be measured by instrumentalist success in effectuating a socially desirable outcome, and by institutional success in preserving the balance of judicial and political roles in the constitutional system. In each of these measures of success, public acceptance of the Court's decisions is assigned great weight by realists, so as almost to rank as an end in itself. To achieve acceptance, and success, requires the Court to select carefully what, and how much, to decide, and how to explain its decisions.

The comments that follow intend to raise some questions about these criteria of the realist tradition-whether they are the proper measure of constitutional law or of judicial performance, and whether they are, indeed, themselves realistic.

To press all the potentially conflicting demands of realism on appellate courts simultaneously can be realistic no more than it is logical. The instrumentalist critique of a Supreme Court decision, for instance, may rest on ascribing to the Court pragmatic objectives different from the constitutional premise whose principled interpretation is invoked in the case. On the other hand, judicial determination to produce the responsible result may prove to be a disfavor to the institutional system, while an untenable outcome may stimulate rapid and effective political reform. Preoccupation with the odds of effective compliance may undervalue the social importance of an announced principle for its own sake, or the social cost of failure to announce it. "Realistic" concern about the political acceptability, either of substantive doctrine or of judicial intervention, may prove to reflect only an unsophisticated misreading of political realities. The realist style in opinions may be misleading as to doctrine and in practice diminish rather than enhance public acceptance of a decision.

These weaknesses of the realist calculus are illustrated by scholarly criticism of leading decisions of the Warren era. More important, however, the single-minded focus of constitutional law scholarship on the performance of a "Warren Court," or on the Supreme Court in any era, without reference to other courts and institutions distorts both the reality of constitutional adjudication and its logic, with adverse consequences to constitutional law itself.

\section{The Instrumentalist Fallacy}

The realist method of criticism-ascribing to the court some pragmatic social goal which its decisions are then shown not to have achieved-is exemplified by the attack on the reapportionment deci- 
sions establishing that equal protection requires numerically equal representation in state and local legislative bodies. Bad enough, thought the critics, that the Court had addressed itself to a problem which was practically irrelevant, because state legislatures are largely irrelevant, and that its formula was "simplistic," the scholarly realist's most damning adjective for a judicial decision. ${ }^{10}$ Worse, the Court must have had in mind some reforming purpose, and its decision failed both as diagnosis and as prescription. "State government was sick. But it is highly unlikely that malapportionment of its legislature was the cause of its illness or that reapportionment would effect a cure," wrote Kurland, concluding that the Court had provided no "justification" for its ruling except "as an exercise in arithmetic." 11 The reapportionment decisions were a success by the tests of compliance and public acceptance; yet insofar as their object was to revive state legislatures, transfer power to city dwellers, or provide more "meaningful" representation, they failed. ${ }^{12}$ The supposed reform was not only ineffectual but misguided in an age of group rather than individual politics. ${ }^{13}$

A characteristic weakness of realist criticism appears in these attacks on the reapportionment decisions-the commingling of two kinds of criteria. Assessment of the real effects of a court's ruling, simple result orientation, represents the critic's independent evaluation of the ruling. But criticism of a court's performance on instrumentalist grounds is different, for here success or failure is measured by the goal values of the court, not those of the critic. Thus, the criticism depends on the attribution to the court of pragmatic goals beyond the normative premises stated in the ruling itself. With respect to the reapportionment decision, the heart of Professor Bickel's criticism is the postulate that the Court's philosophical purpose was to enforce a majoritarian view of the democratic process. In his Holmes lectures, Bickel devotes a major section to showing that the majoritarian premise raises but does not resolve the problem of defining the community or district within which a given constituency is to have individually equal votes. "The Court has said that the majority must rule. Now the question is, which majority?" 14 The question is central to Bickel's main theme, his conviction that progress lies in the direction of pluralism and in the greater self-determination of social groups. Moreover, Bickel sug-

10. Politrcs 83.85, quoting Freund, New Vistas in Constitutional Law, 112 U. 'A. L. REv. 631, 639 (1964).

11. Id. at 84,92 .

12. PoLrTics 161-62.

13. IDEA OF Progress 151 et seq.

14. IDEA OF PROGRESS 152. 
gests that the Court's supposed majoritarian premise casts doubt on democratic practices which require more than a simple majority vote for purposes such as deciding upon constitutional amendments or incurring governmental debts. ${ }^{15}$ Kurland also assumes a majoritarian premise and therefore castigates the Court's refusal to allow Colorado voters to malapportion one legislative house by referendum. ${ }^{16}$

But the Court did not hold that "the majority must rule." Although a part of the argument against geographic districts of unequal population was that such an arrangement allows a minority of voters to elect a majority of legislators, ${ }^{17}$ election of representative bodies by districts will always make such an occasional outcome possible, no matter how pure the ratio of representation among districts. This possibility seems inconsistent with the Court's one man, one rote doctrine only after that doctrine has first been attributed to a majoritarian premise, rather than to the egalitarian one from which it was deduced. The Court did not impress plebiscitary democracy on state and local government; it has, in fact, been soundly suspicious of the threat of plebiscitary majoritarianism to the constitutionally sensitive interests of minorities. ${ }^{18}$ What the Court did hold was that when a state gives the same elected representation to more as to fewer persons, it denies each member of the larger group the equal protection of the law. True, this reflects a view of the equal protection clause based on individual, not group, citizenship; but that was hardly new. ${ }^{10}$ And since the operating premise of the apportionment decisions was really equal protection, not majoritarianism, Bickel's doubts about laws requiring more than majority votes were proved unfounded when the Court later sustained a state's sixty per cent requirement to pass a bond or tax measure. ${ }^{20}$

15. Id. at 152-53.

16. "A legal doctrine originated to assure majority rule was thus held to preclude a right of the majority to establish its rulc." PoLrmas 85 , criticizing Lucas v. Colorado General Assembly, 377 U.S. 713 (196-1).

17. Logically, in a society ostensibly grounded on representative government, it would seem reasonable that a majority of the people of a State coufd elect a majority of that State's legislators .... Since legislatures are responsible for enacting laws by which all citizens are to be governed, they should be bodies which are collectively responsive to the popular will. . . . Our constitutional system amply provides for the protection of minorities by means other than giving the majority control of state legislatures.

Reynolds v. Sims, 377 U.S. 533, 565-66 (1964).

18. Hunter v. Erickson, 393 U.S. 385 (1969); Reiman v. Mulkcy, 387 U.S. 369 (1967); see also Pierce v. Society of Sisters, 268 U.S. 510 (1925).

19. See Shelley v. Kraemer, 334 U.S. 1, 11 (19:8):

The rights created by the first section of the Fourteenth Amendment are. by its terms, guaranteed to the individual. The rights established are personal rights.

20. Gordon v. Lance, 403 U.S. I (1971). 
It is, of course, possible to construct from the equal protection clause a majoritarian argument that such rules (designed to make some public acts more difficult) deny political equality to those who favor the proposed action. Yet a more-than-majority requirement still treats each voter, when he enters the voting booth, as an equal individual. When such a built-in bias against passage of a proposed measure is claimed to deny political equality, a claim of discriminatory classification must be shown from the nature of the category disadvantaged by the challenged requirement, not from the mere denial of majority rule as such. ${ }^{21}$

If the reapportionment decisions do not assure majority rule, if they cannot revive financially bankrupt state legislatures, or if they complicate the representation of discrete constituencies in metropolitan government, were they therefore mistaken? They may be criticized as mistaken-"irrelevant," "obsolescent," or an instance of needless judicial hyperactivism-only after one has ascribed to the Supreme Court the pragmatic reformist purposes according to which success is then measured. Couldn't it be that the "exercise in arithmetic" was its own justification in the principle it established? The popular approval of the one man, one vote doctrine demonstrates that the Court and the public shared a premise quite beyond any expectation of practical results from the reallocation of power-the premise of equality of citizenship as a constitutive principle in American politics for its own sake, as a means to no "realistic" end other than a renewed sense of the principled legitimacy of the whole political enterprise.

\section{The Pitfalls of Statecraft}

"Success," by the criteria of realist criticism, calls for judicial "statecraft" not only in the selection and achievement of pragmatic social goals, but also in a politically realistic regard for institutional considerations-both with respect to the successful functioning of the constitutional system as a whole and in the narrower sense of preserving the Court's own institutional role and effectiveness. Yet political realism in assessing the effects of a decision and the responses of other institutions and of the public is a luxury of critical hindsight that is most problematical as a premise of adjudication. Even in hindsight, a decision that may appear inescapable in view of social and political "realities" may not have been necessary for the sake of either the constitutional system or the Court, while decisions that seemed doomed to

21. Hunter v. Erickson, 393 U.S. 385 (1969). 
institutional frustration, or dangerously self-destructive, may turn out to be neither. These pitfalls of "statecraft" can be illustrated by Bolling v. Sharpe,22 Oregon v. Mitchell,23 and Powell v. McCormack.94 The first of these omitted all examination of constitutional premises in a rush toward a "realistically" inevitable outcome whose apparent inevitability might well have merited closer scrutiny. In the second, the politically most principled result followed upon a failure of judicial statesmanship to reach any conclusion tenable either in principle or in practice. The third decision, an apparently Quixotic gamble of the Court's institutional capital in political Russian roulette, proved to be sound in principle and safe in politics.

When the Court decided in Brown v. Board of Education"s to end state racial segregation under the equal protection clause, the outcome in Bolling, the companion case from the District of Columbia, scemed obvious. After a few abstractions about "unreasonable discrimination" as a denial of due process of law, the Chief Justice's short opinion states the operative premise:

In view of our decision that the Constitution prohibits the states from maintaining racially segregated public schools, it would be unthinkable that the same Constitution would impose a lesser duty on the Federal Government. ${ }^{20}$

Just six years earlier, when the equal protection clause was held to prevent enforcement of racially restrictive covenants, the Court had given the unthinkable enough thought to preclude such a constitutional holding for the District.27 Of course, there is nothing difficult or even surprising in the thought that the "same Constitution," in the equal protection clause of 1868, might impose upon the states congressionally enforceable standards of equal treatment beyond that im. posed upon the federal government by the Fifth Amendment in 1791 -at least nothing unthinkable if the premises for this thought are to be found in the text, the history, or the political structure of the Con-

22. 400 U.S. 112 (1970).

23. 395 U.S. 486 (1969).

24. 347 U.S. 497 (1954).

25. 347 U.S. $483(1954)$.

26. Bolling v. Sharpe, 347 U.S. 497,500 (1954).

27. Shelley v. Kraemer, 334 U.S. I (1948), Hurd v. Hodge, 334 U.S. 24 (1948). P'ro. fessor Kurland misstates Hurd in PoLrrics 109, as holding that the equal protection clause is applicable to the federal government by incorporation in "due process" (an application which the Chief Justice took pains to deny in Bolling v. Sharpe, 347 US. at 499). His mistake seems to be common. In Hurd the Court expressly rested decision on the Civil Rights Act of 1866 and declined to reach the constitutional issue of the 5th Amendment. 394 U.S. at 30 and n.7. 
stitution. What defied thought in Bolling was the suggestion that a mere doctrinal distinction between the Fifth and Fourteenth Amendments could confine the scope of a revolution in the constitutional law of race relations. It was the political implication of such a distinction, seen in the broad terms of judicial statecraft, that made it "unthinkable."

But the unthinkable often bears thought. What would have been the consequence of a decision that the states could not segregate by race because of the federal limitations imposed upon them at the end of the Civil War, but that the Reconstruction amendments had left Congress, their initiator, to shift for itself? Such a decision would have undoubtedly been attacked as a pedantic lesson in constitutional history and as a failure of judicial creativity in refusing to find a dynamic principle of equality in the Fifth Amendment's due process clause.

And what of the political institutions? They could not have left the situation to remain where the decision had left it. Congress would at once have taken up debate of the question of desegregating the District's schools. Southern members could have insisted on extending the principle of desegregation equally where the Court had not, to all federal and state governments alike, a political escape route from massive resistance which some of them discovered a dozen years later. ${ }^{28} \mathrm{~A}$ President who had nothing to say about Brown could not well have remained silent about the federal District. With serious congressional work on civil rights legislation having been foreclosed for years only by Southern filibusters, the ultimate outcome could not have been seriously in doubt. Is it at least thinkable that the Constitution itself, having at a historic time placed equal protection into an amendment addressed specifically to the states, might still be realistic about the American political reality?

We do not know that events would have followed this course. Nor is the present point whether desegregation in the District was or was not compelled by a correct analysis of the Fifth Amendment. I mean only to suggest that the answer cannot be made to depend upon a "statesmanlike" calculation of the political consequences, either by judges or by their critics. "Realism" in concluding that a different decision in Bolling was unthinkable describes a judgment not of the Court but about it.

The preoccupation of constitutional law scholarship with the Su.

28. Cf. A. Bickel, The least Dangerous Brancil 254-58 (1962). 
preme Court undervalues the capacity of the constitutional system to deal with dilemmas left unresolved in constitutional decisions by the courts. This was illustrated by Congress's response to Oregon $v$. Mitchell, ${ }^{29}$ a decision that lacked political "realism" as much as my hypothetical scenario for Bolling. After Congress, thoroughly briefed and conscious of the close question of its constitutional power, sought to give 18-year-olds the vote by statute, the Supreme Court sustained the law with respect to voting for federal offices but not in state and local government elections.

As an event in constitutional growth having a direct bearing on political processes and their constituencies, Oregon v. Mitchell ranks in constitutional importance with the reapportionment decisions and the federal enfranchisement of Southern Negroes. But the decision itself was incongruous on every score. Four justices thought that Congress was empowered by section five of the Fourteenth Amendment to lower the voting ages of the several states as an enforcement of the equal protection clause; five did not. Four thought that Congress could lower the states' age qualifications of voters in any election; five did not. Eight justices did not find a power to alter age qualifications for federal elections in the provision of Article I, section four, that Congress may alter the regulations of the states as to "the Times, Places and Manner of holding Elections for Senators and Representatives"; one, Justice Black, did, and his distinction between eligibility to vote for federal and for state offices became the effective holding of the case. ${ }^{30}$

The result was doomed from the start. The political situation could not remain where the decision left it. In the wake of the confusion and curses among state election officials, the Court's holding brought virtually instantaneous reexamination by Congress and the country as to whether they did or did not want the eighteen-year-old vote. The real constitutional decision was made ultimately by the Twenty-sixth Amendment. ${ }^{31}$

29. 400 U.S. $112(1970)$.

30. The idea that it might be exercising an authority under Article I, section four, to alter the age qualification of voters for federal but not for state offices had never oc. curred to Congress throughout the long constitutional debate on the act. See Mikia \&: Lundy, The 9lst Congress and the Constitution, 38 U. CiI. L. REv. 449, 479.85 (1971). 31. U.S. CoNsT., amend. XXVI (1971):

Section 1 . The right of citizens of the United States, who are eighteen years of age or older, to vote shall not be denied or abridged by the United States or by any State on account of age.

Section 2. The Congress shall have power to cuforce this article by appropriate legislation. 
Oregon v. Mitchell is a textbook case of a decision which was not only wrong by the premises of any combination of the justices, but which also flew in the face of "realistic" statecraft. Since a clear decision either to affirm the statutory eighteen-year-old vote or to leave it entirely to constitutional amendment would have spared Congress and the country the urgency of quick action, it seems clear at first blush that the statesmanlike duty to avoid constitutional confusion should have impressed itself on the Court's lonely majority of one. But is it still so clear on second thought? Who is to judge the perception of political reality of an old ex-Senator who might believe that a constitutional change having such a direct bearing on the nation's political processes should be faced soon-but that it should be faced by constitutional amendment?

Predictions about the political consequences of a decision are likely to be simplistic, and those of judges and professors will be scarcely less so than those of newspapermen and politicians. Surely political realism would counsel against taking up, and then reversing, the exclusion of Adam Clayton Powell ${ }^{32}$ by the House of Representatives, in view of the potential damage to already fragile relations between the Court and Congress. Should the Court risk outraging the denizens of the very heart of the political thicket, in a cause in which its action might well be ineffectual anyway? The fears proved groundless. The Congressmen's imperative need to display a firm stance toward Powell had been adequately discharged by their votes, and many of them were not displeased to be taken off the hook by the Court. Both as guardians of their own institution and as individuals subject to its rules, they were not uncomfortable to know that their constitutional premises might find judicial guidance and review..$^{33}$ But the capacity of either judicial or scholarly realism to discern this political reality is a slender reed on which to rest constitutional judgment. It was not the fact that the Court "got away with it" that vindicated its reading of the Constitution in Powell; nor would a different political reaction have proved it wrong. The decision must be made and judged in other terms. Judicial pursuit of statecraft by political guesswork, whether for the good of the polity or the Court's own institutional interests, offers no more cogent or compelling premise for constitutional decision than the achievement of pragmatic social goals.

32. Powell v. McCormack, 395 U.S. 486 (1969).

33. This view is set forth in more detail in Linde, Comments on Powell v. McCormack, 17 U.C.L.A. L. REv. 1, 174 (1969). 
Judges, Gritics, and the Realist Tradition

\section{The Uses of Unpopularity}

What of popular acceptance-regarded in the realist canon as the sine qua non of its measures of judicial success? A number of the decisions disparaged by realists on instrumentalist grounds-the reapportionment rulings, for example-have won wide popular acceptance for their principles. If public acceptance and compliance prove a decision right, unpopularity and widespread evasion should prove another decision wrong. By such a test, the classic failure of the Warren era would be the decisions against officially sponsored prayer and Bible reading in public schools. ${ }^{34}$ For millions these rulings were unquestionably the great outrage of the Warren years. Social scientists gleefully seized upon them as the ideal subject for impact studies and similar demonstrations of the gap between law and social reality. "The effectiveness of the prayer decisions as operational law in our society is very minor indeed," Bickel notes, for they lacked the acceptance by the general public that is the "ultimate secret" of effective law. ${ }^{35}$ Similarly Kurland, insisting that, "One must look to see not only what the Court has said but what its words have accomplished," cites continued school prayers and Bible reading as a cardinal illustration of failure. ${ }^{30}$

Again, the implicit premise is that compliance, the actual ending of school prayers, is the chief object of the Court's action and the measure of its success. And again, it is a realism preoccupied with practical results, with the "effectiveness" of law to control behavior, that seems simplistic. For many of the protagonists in Establishment Clause cases, surely, what counts is the principle itself, quite apart from its realization in some concrete situation. At stake is reassurance, for one side, that the Constitution establishes a secular public order which recognizes no preference for religious convention or belief, and for the other side, reassurance of something nearly the opposite. The issue is no less real for being stated in symbols, nor is a Supreme Court victory a less effective source of reassurance for meeting with opposition and non-compliance.

Recognition of this significance of constitutional holding for its own

34. School Dist. of Abington Township v. Schempp, 374 U.S. 203 (1963); Engel v. Vitale, 370 U.S. 421 (1962).

35. IDEA OF PROGRess 91-92. The prajer decisions were discussed at a special round table session pertaining to the impact of Supreme Court decisions, at the 1969 annual meeting of the Association of American Law Schools. The meeting was devoted to the theme "Social Research and the Law."

It should not be assumed that the decisions had no significant effect; sec, e.g., Way, The Impact of Supreme Court Decisions on Religious Practices in Public Schools, 21 West. Por, Q. 189 (1968).

36. Polmics xix. 
sake thus suggests a different test for some of the Court's most important decisions: the test of the hypothetical opposite. If realism would weigh constitutional decisions by a cost-effectiveness ratio, it must bc prepared to consider the implications of a decision opposite to that being weighed. What would be the implications for the Constitution, in its role as primary national symbol, of a decision saying that a bit of organized public prayer never hurt anyone? That a little inequality of voting rights did not matter as long as the state thought it served a useful purpose in some larger political scheme of things? That it was no injustice to ransack someone's home or wire it from floor to ceiling, if the evidence obtained proved him guilty of a crime? Or that difficulties of effective schooling, of peaceful public recreation, or of mixcdrace families might on occasion justify evenhanded segregation? The value at stake is far more than programmatic effectiveness. There is a "mystic function," as Bickel earlier termed it, ${ }^{37}$ that is inescapable in opinions explicating the Bill of Rights. If the Court held that a little non-denominational school prayer is not really an establishment of religion, the cost to the losers would be more than the fact that this "legitimation" 38 would assure the spread of prayers even to schools that before had none. It would shape people's vision of their Consti. tution and of themselves. Critics of Brown and its per curiam sequels must calculate the cost, to the nation's self-image as well as to the possibilities of political action on civil rights, of an alternative opinion allowing continued legitimacy to Plessy's mirage of segregated equality. In all these areas, judicial pursuit of the realists' seductive criterion of popular success would inevitably point toward decisions that would undervalue the important role of announced constitutional principle apart from compliance.

\section{Realism as a Judicial Style}

The realist criteria of judicial success-instrumental effectiveness, institutional self-regard, and public acceptance-are not, I have suggested, an adequate measure of the substance of constitutional decisions. Nor are judges most successful when they articulate their reading of the Constitution by the precepts of realism. Ironically, the style of explanation that realism has made traditional, comprised of recitations of social diagnosis and explicit policy goals, is as likely as not to be counterproductive for the practical success of the Court's constitutional

37. A. Bickel, The Least DANGerous Brancil 29 (1962).

38. The term Bickel adopted from Professor Charles Black. Id. 
holdings. The two great undertakings of the Warren Court that did have to bid for compliance and enforcement over widespread public and political opposition-desegregation and the reform of criminal procedure-were hurt rather than helped by the "realistic" premises offered in their justification.

Brown $v$. Board of Education ${ }^{39}$ invoked realism in the form of social diagnosis. The Supreme Court's citation of a number of published psychological studies as support for judicial findings that segregation inherently retarded the educational development of Negro children was widely hailed or anathemized as a breakthrough for social science in the law. ${ }^{40}$ And yet the dispute over the use and validity of these studies added a wholly needless tempest in a teapot to the incscapable storm over the Court's holding. The outcome in Brown could no more depend on the presence or absence of expert testimony than could the constitutionality of the 1964 Civil Rights Act depend on congressional testimony about the impact of segregation on the consumption of restaurant meals by Negroes. ${ }^{41}$ Even had no studies and no psychological findings existed, it was inconceivable that the Court in 1954 could have reaffirmed the constitutional endorsement of racial segregation in Plessy in 1896.42 Long before Chief Justice Warren's appointment, Plessy had been doomed to eventual overrulingt3 by a recognition that it was wrong in principle. As Edmond Cahn noted at the time, ${ }^{\text {th }}$ suggesting that the decision hinged on new found facts served only to detract from the historic recognition of a constitutional imperative. The presence of empirical evidence in the opinion suggested that this constitutional imperative was no better than its stated factual assumptions and invited, quite misleadingly, dispute about them. If the outcome does not actually depend on the recited facts, the realist mode of justification is a sham or a mere tactical choice among styles of opinion writing. Thus, the recital in Brown of psychological premises about school children earned the Court much criticism when it later applied the holding per curiam to all types of segregation unrelated to

39. 347 U.S. 483 (1954).

40. Id. at 494 n.11. Some of the literature is cited in WY. Lockinast, Y. Kasisis \& J. Choper, Constitutional Law (3d ed.) 1203, note a.

41. Katzenbach v. McClung, 379 U.S. 294 (1964).

42. Plessy v. Ferguson, 163 U.S. 537 (1896). The Sixth Circuit Court of Appeals recently cited Brown to limit desegregation, by judicial notice that "feelings of inferiority" vould be generated by busing children from neighborhood schools because of the color of their skin, and instructed the lower court to read a citcd psjchological article on the subject. Mapp v. Board of Education, 41 U.S.L.W. 1057 (6th Cir. Oct. 11, 1972).

43. PoLrrics xvi.

44. Cahn, Jurisprudence, 30 N.X.U. L. REv. 150 (1955). 
schools, ${ }^{4 \overline{5}}$ criticism which would have been avoided had Brown been based explicitly on an interpretation of the Fourteenth Amendment striking at racial segregation by law, of which the schools would have been only the immediate and most difficult case. ${ }^{40}$

The Supreme Court's encounter with unconstitutional practices in law enforcement reveals the problems posed when realism bases constitutional rules on explicit premises of social engineering. This mode of explanation only provided a rationale for non-compliance and for open political attack on constitutional guarantees. The explication of the exclusionary rules ${ }^{47}$ became increasingly instrumentalist as the decade wore on, explicitly resting on the need to deter general policc misconduct, perhaps because mere principled enforcement of constitutional guarantees directed against the police and invoked by criminal suspects had met with little instinctive assent by public and judges. Yet, as a recent study by Professor Dallin Oaks demonstrates, ${ }^{48}$ the instrumentalist "justification" is self-defeating when used as a premise for Fourth Amendment rights. For when a constitutional rule that a man may not be convicted through the use of official misconduct is "justified" on the pragmatic ground of deterring such misconduct, the rule can be defeated simply by the relevant official's refusal to be deterred. That, of course, is exactly what both Professor Oaks and the successors to the Warren Court argue. ${ }^{40}$ Some years before he became Chief Justice, Judge Burger attacked the exclusionary rule on the instrumentalist ground on which the Supreme Court had chosen to place it, and he has since taken the opportunity to publish his proposals for substituting other legal devices for the rule..$^{50}$ If instrumentalism of this sort seriously explained the source and rationale of the exclusionary rule, its logic would point toward refinements of the rule so that evidence must be suppressed, as a matter of due process for the defendant, wherever suppression is thought to deter officers and not

45. Politics 124.

46. Not only in practical execution, but also in constitutional theory the case of schools poses problems not presented by laws enforcing racial segregation in other pub. lic facilities. It is especially difficult to derive from either the sociological or the historical premises of the equal protection clause the assimilationist duty of the public schools that so troubles Professor Bickel, IDEA OF Procress 121-39, when a localized cthnic minority, wishing to maintain its cultural identity, resists enforced dispersion in the public schools, as in San Francisco's Chinatown, see Johnson v. San Froncisco Unified School Dist., 339 F. Supp. 1315 (N.D. Cal.), petition for stay denied, sub. nom. Gucy Hcung Lee v. Johnson, 404 U.S. 1215 (1971).

47. See, e.g., Mapp v. Ohio, 367 U.S. 643 (1961).

48. Oaks, Studying the Exclusionary Rule in Search and Seizure, 37 U. CHII. L. REv. $665(1970)$.

49. Id. at 720-57.

50. Bivens v. Six Unknown Agents, 403 U.S. 113 (1971) (dissenting opinion); Burger, Who Will Watch the Watchman?, 1 AM. U.L. REv. 1 (1964). 
where it is not: matching the rule to the reason would produce a constitutional right for some but not for other defendants, depending on whatever empirical generalizations could be found to determine the "effectiveness" of the rule in different kinds of social and institutional settings of police work.

Such a display of judicial realism and candor refers the opponents of the rule to the Court rather than to the Constitution as the source of the rule, thereby inviting the charge that the judges are out to handcuff the police and encouraging efforts to replace judicial with legislative pragmatism. "A decision of the Supreme Court, if it is based on a factual assumption which is incorrect, may be subject to Congress' power to legislate," said Senator Ervin in defense of Senator McClellan's bill to overturn the Miranda rules on the admissibility of confessions.

The Supreme Court has no right to make constitutional determinations based on unsound factual assumptions. I don't believe the great majority of law-enforcement officers in the United States are such disreputable people that they have to have the criminals protected against them..$^{51}$

Furthermore, justifying the exclusionary rule as a deterrent of police misconduct rather than as due process for the defendant confuses the public understanding of the principles involved. When the Supreme Court under Justice Burger holds that a suspect's statements obtained without the Miranda warnings may be admitted against him for some purposes, ${ }^{52}$ the public is given to understand that the decision modifies not only trial procedures but loosens the Miranda obligations of the police themselves. If the Court should eventually rule that otherwise uncoerced statements may be admitted for all purposes, both the public and police may well take this to mean that Miranda warnings are no longer constitutionally required. Indeed, the campaign of law enforcement agencies and of many politicians against the several exclusionary rules surely reflects an assumption that an end to these rules would mean an end to the requirements of being careful with arrests and with searches, of cautioning suspects, providing them with lawyers upon arrest, or speeding them before magistrates. Otherwise, what was the President's great battle for a "judicial philosophy" favor-

51. Hearings Before the Senate Judiciary Comm., Subcomm. on Separation of Pouters, 90th Cong., 1st Sess., at 25 (1967).

52. Harris v. New York, 401 U.S. 222 (1971); Miranda v. Arizona, 384 U.S. 436 (1960). 
ing the "peace forces" against the "criminal forces" about? Of course, as a matter of constitutional logic the assumption is nonsense; an abandonment of the exclusionary rules would not in itself revoke the rights of the suspect and the obligations of the police under the Fourth, Fifth, and Sixth Amendments as developed in prior case law. Yet given the instrumentalist terms in which the exclusionary rulc was first presented, a subsequent decision to abandon such judicial enforcement must appear as no mere thoughtful reexamination of a problem in constitutional interpretation, but as a decision to free law enforcement from compliance with the substantive obligations them. selves.

A different premise may be found, and in the Constitution, at that. It is that no person is to be deprived of life, liberty, or property without due process of law. To hold that a process in which public officers ignore a defendant's constitutionally guaranteed rights is not the "due process" of the Constitution asserts that the due process clatuse is concerned with the individual immediately jeopardized by the process, not merely with optimizing the system's efficiency or with protecting the government's moral reputation. ${ }^{53}$ It is assertive about a judicial elt1cidation of a constitutional text rather than a description of social reality and a preferred policy choice.

Judicial recital of "realistic" premises may thus be more hindrance than help in explaining and justifying a constitutional ruling intended for general and varying application, whether the premise is diagnostic, as in school desegregation, or instrumentalist, as in criminal procedure. In some areas of adjudication, such as commerce clause limitations on state law, the new equal protection, or the application of the First Amendment, constitutional consequences have often been made to depend on a case-by-case evaluation of concrete facts. But it is misleading to justify general constitutional rules or principles by the Supreme Court's perception of facts, when the presence or absence of such supposedly decisive facts is not thereafter open to examination by either lower courts or lawmakers-as the psychological and social consequences of segregation or the actual "chilling effect" of various city ordinances or disclaimer oaths clearly were not. Such "factual" justification of per se rules in constitutional law is a far cry from the realism of a Brandeis brief supporting the judgments of legislators against charges of irrationality, or of Justice Stone's examination of

53. Cf. Wolf v. Colorado, 338 U.S. 25, 47 (1949) (Rutledge, J., dissenting); Allen, Fed. eralism and the Fourth Amendment: $A$ Requiem for Wolf, 1961 SU1. CT. REv. 1. 
the economic and political realities of state regulation and taxation of interstate commerce. ${ }^{5 t}$ When a holding is rightly a principled interpretation of the Constitution, it is not strengthened by masquerading as a constitutionally irrebuttable finding of fact. The proper use of sociological premises in constitutional adjudication is not, as one expert with a foot in each camp has recently termed it "toys, facades, or security blankets," 55 nor should subjective judicial notions of such premises be invoked to bolster decisions that are grounded in precedents, interpretations of texts, or moral precepts. ${ }^{50}$ When, on the other hand, success by every practical test-compliance, popular acceptance, respect for the institution of the Court-is achieved by a decision that purports to be based on broad constitutional principle, realist critics will grumble about judicial method. A classic example is the Steel Seizure case. ${ }^{57}$ Commentators never tire of noting that, with four concurrences based on narrower grounds of congressional policy and three dissents, the decision does not stand for the broad constitutional assertions announced in Mr. Justice Black's "Opinion of the Court."

Undoubtedly any competent assistant attorney general could demonstrate for a future president that a "real" majority of the Supreme Court had not foreclosed all domestic emergency action against private persons or property in the absence of a congressional policy. But that is not realism. Beyond any nose count or reinterpretation of opinions, the Steel Seizure case has achieved a life of its own as a great constitutional decision imposing limits on the executive prerogative beyond any lawyer's narrowing. Whatever its analytical shortcomings as legal doctrine before some future court, it has drastically raised the cost of unilateral action in the first forum relevant to such presidential action-in the public and congressional understanding of the Constitution.

In 1971 Professor Bickel had occasion to invoke, quite rightly, the Steel Seizure case in his argument before the Supreme Court against a purely executive order forbidding publication of the Pentagon

54. Strikingly, after the deaths of Chief Justice Stone and Justice Rudedge, the Supreme Court under the influence of Justice Frankfurter lost interest in the realistic style in this sphere; see Huron Portland Cement Co. v. City of Detroit, 362 U.S. 440 (1960); Freeman v. Hewitt, 329 U.S. 249 (1946).

55. Rosenblum, A Place for Social Science Along the Judiciary's Constilutional Lan Frontier, 66 Nw. U.L. REv. 455, 479 (1971). Unlike the more cnithusiastic adrocatcs of social science in the law, Professor Rosenblum claims no stuperiority for Lchasioral over authoritarian premises in judicial justifications, but he objects to unfounded judicial assertions of alleged social facts that are susceptible of cmpirical determination. Id. at 459.

56. See Hazard, Limitations in the Uses of Behavioral Sciences in the Lan', 19 CisE W. RES. L. REV. 71 (1967).

57. Youngstown Sheet \& Tube Co. v. Sawjer, 343 U.S. 579 (1952). 
Papers. Again the circumstances of the case brought a proliferation of opinions, prefaced by a minimal per curiam, written in greater haste than the earlier decision and individually less satisfactory. ${ }^{58}$ Confined to its narrow preoccupation with prior restraints, the decision may prove a Pyrrhic victory for the press, if a count of the Justices and analysis of their several opinions causes the government and lower courts to move toward post-publication penalties. Yet unless this happens soon, the Pentagon Papers case may achieve, even without the benefit of a "vacuous" and "meaningless" opinion for the Court in the style of Mr. Justice Black, the same success by the measure of history, the same status in constitutional reality, as the Steel Seizure decision. In the forum of the public and congressional understanding of the Constitution, the principle which emerged will stand for more than what a majority of the Justices aspired to decide, and this common understanding can impose a prohibitive price on government action, long after criticisms of the Justices' disagreements and of their particular premises has been forgotten.

II

The preoccupation of constitutional scholarship with the United States Supreme Court has shortcomings beyond the inconsistent and sometimes illogical demands of legal realism on judicial opinions. The perspective of recent criticism on the Warren Court is at once too broad and too narrow-too broad in attempting to apply a general doctrinal critique to an almost unprecedented diversity of indiviclual Justices' positions in a wide variety of substantive fields; too narrow in ignoring the importance of other courts and governmental institutions.

\section{Critical Overbreadth}

That a critical focus on the Warren Court is too broad is due, in part, to a proliferation of substantive fields with which the Court deals. Critical commentaries during the Supreme Court's last previous era of controversy, when the preceptors of today's scholarly tradition were young, could concentrate on the Court's application of the commerce clause and the due process clause to the regulation of business activities. The tasks of criticism were kept manageable both by the

58. New York Times Co. v. United States, 403 U.S. 713 (1971). 
nature of the substantive and methodological issues and by the fairly consistent division of the Court on those issues. But the same cannot be said of the Court's modern controversies. The Court's recent work has spawned new fields of constitutional expertise about erotica, police searches, electoral systems, school district boundaries and pupil assignments, libel, public employees, post-conviction procedures, street demonstrations, public housing and welfare procedures, and many more. Each area calls forth reams of history, analysis, and policy, which emerge from specialists in sober studies and in imaginative pleadings. The list alone is, of course, the distinguishing mark of the Warren era. But as subjects of a coherent critique, these diverse developments strain the generalist's need to attend to the particular while remaining faithful to a larger whole.

So do the paradoxes of collegial performance. "[L]atent in references to the 'Supreme Court,' " as the editor of Justice Brandeis's unpublished opinions reminds us, there is what Thomas Reed Powell called an "unwarranted animism." Although the authority of the Court rests in part upon premises of continuity and internal constraints inherent in collective decision, the processes of judgment, in method as well as philosophical commitment, are inescapably personal. Reasonable demands for collective performance must coexist with equally reasonable demands for consistency, cogency, and commitment set for the individual judge by himself and those who observe his work. The two demands must often conflict, particularly on the Supreme Court, when narrow divisions over strongly opposed doctrines are altered by the departure and arrival of justices committed to one or the other view. ${ }^{59}$

Professional appraisal cannot simply attribute to the "Warren Court" everything that was decided by the Supreme Court between October 2, 1953, and June 23, 1969. Sixteen associate justices served during the tenure of Chief Justice Warren. ${ }^{00}$ Who was the "Warren Court" and

59. Critical dissatisfaction with collective doctrines is exceeded by the disrespeet accorded a record of contradictions, fallacies, or intellectual fecbleness in the opinions of the individual justice. Not only has serious criticism honored the judge who over time has developed and maintained strongly principled positions in constitutional adjudia. tion; this recognition is shared by the public, as the comments following the recent departures of Justices Black and Harlan show, and cventually by biography and general history. The temptation to merely idiosyncratic expression finds bounds in the needs and traditions of collegial decision; still, when resignations and deaths bring new men of ability and conviction to join others who have long articulated their own lines of substance and style, it is a wonder that the tradition of opinions for the Court has remained the rule rather than the exception.

60. They included (with dates showing their overlapping years of sen ice) Hugo $L$. Black (1937-71), Stanley F. Reed (1938-57), Felix Frankfurter (1939-62), William O. Douglas (1939-present), Robert H. Jackson (1941-54), Harold H. Burton (1945-j8), Tom C: 
what were "its" doctrines? Was it merely those justices composing the changing majorities, or those who set the tone and style of its debates? For Justices Black and Douglas-the two whose service both long preceded and continued past the Warren years-the Court's best-known work in the 1960's was but the partial and belated recognition of constitutional principles emergent since 1938, which might have commanded a majority earlier had it not been for the deaths of Justices Stone, Murphy, and Rutledge, and the choice of their successors. These principles were tenaciously opposed during most of the Warren years by the most influential survivor of the pre-Warren orthodoxy, Justice Frankfurter. Does attribution to the "Warren Court" encompass Justice Clark, who was prepared to adopt the exclusionary rule a decade before the Court for which he wrote Mapp $v$. Ohio, ${ }^{01}$ and who all* thored the proscription of religious texts from public school exercises, ${ }^{02}$ but who also fought for the internal security and loyalty programs? Does it exclude Justice Harlan, the tireless adversary of the direction and style of the later years whose dissents provide appraisal of the period with much of its dialectic? Yet in First Amendment doctrine, who is it that represents the "Warren Court" in Street v. New York'-Harlan speaking against a flag-burning conviction, or Warren dissenting along with Fortas, White and Black?

Thus, one sympathizes when Professor Bickel, obliged to lecture in some fashion about the collective institution, reduces the unwarranted animism to a "dominant majority that gave the Court its character [which] consisted over the years of the Chief Justice and Justices Black, Douglas, Brennan, Goldberg, Fortas, and Marshall."'or When discounted for the fact that the last-named three served only three, four, and two years respectively during Warren's sixteen-year tenure (Fortas being Goldberg's successor), and for what has been noted above about Justices Black and Douglas, this list persuasively implies two points. It shows, first, that what an observer would describe as a real Warren majority was not formed until 1962 when Justice Goldberg replaced Justice Frankfurter, who rightly appears in Bickel's and Kurland's lec-

\footnotetext{
Clark (1949-67), Sherman Minton (1949-56), John M. Harlan (1955-71), William J. Bretl. nan, Jr. (1956-present), Charles E. Whittaker (1957-62), Potter Stewart (1958-prescnt), Byron R. White (1962-present), Arthur J. Goldberg (1962.65), Abc Fortis (1965.69), Thi1rgood Marshall (1967-present).

61. 367 U.S. 643 (1960); cf. Irvine v. California, 347 U.S. 128, 138 (1954).

62. Abington School Dist. v. Schempp, 374 U.S. 203 (1963).

63. See Nelson v. Los Angeles County, 362 U.S. 1 (1960); Greene v. McElroy, 860 U.S. 474, 510 (1959).

64. 394 U.S. 576 (1969).

65. Idea of Progress 130.
} 
tures as the great spokesman for a judicial philosophy counter to the "Warren Court"; and second, that the quintessential figures central to this identification of the era were the Chief Justice himself and Justice Brennan. Yet at the same time Bickel's list strikingly shows that the Court's commitment to the celebrated undertakings of the new direction-racial desegregation, constitutional criminal procedures, legislative reapportionment, expansion of literary freedom, even stringent secularism-came before the "dominant majority" was formed, while this group itself ended badly split on some of the major doctrinal challenges of its last years. The unruly collectivity is not, after all, so easily reduced to a unity. ${ }^{68}$

66. While the diversity of substantive fields and of individual doctrinal positions makes a focus on the Supreme Court too wide for meaningful generalization, this ier diversity might itself be the focus for a critique directed at the Court's institutional methods. In N.Y. Times, Feb. 17, 1968, \$ 6 (magazinc), at 2I, l'rofessor Kurland compared the number of majority, concurring, and dissenting opinions for the five Terms of 1962-66 with the corresponding number of thirty years carlicr. He found that the number of majority opinions for the five years had dropped from 777 to 571 , or an annual average of 155 to 114 , while concurring opinions had multiplied almost fourteen-fold from 13 to 139 and dissents had risen from 86 to 325 , or from 17 to 75 in the average Term. During the period of the Warren Court's supposed "dominane majority," nonmajority opinions exceeded those signed by a majority. The tigures bear out, of courst, the fallacy of reducing the Warren Court to the simple bi-polar model of opposing schools of thought that characterized the Court in the era of Chief Justice Hughes. Nevertheless, the critics might be asking whether so many opinions are necesary, whether perhaps the justices without adopting the customs of Marshall's day or of most state courts, let alone the logical formalities of European judmments, might sacrifice a little of their individual records of reason and eloquence to the institutional cause of more coherent collective statements of both the prevailing and the dissenting positions.

Kurland's point, however, is somewhat different. It is the familiar one that the volume of the Supreme Court's work overtaxes the justices capacity to produce opinions that can give coherent expression to the premises of the Court's judgment and, if necesary; of the dissent, and his proposed solution is to limit the Court's jurisdiction to cases involving a constitutional question. But he does not regard multiplicity of opinions as evidence of malfunction and concedes that additional time might produce eren more opinions. Bickel, too, prefers "six separate opinions without an opinion of the Court .. in which each judge travels but travels well his own intellectual road, even if there is no common destination except in the result," to the "vacuity" of "a desperately negotiated document" such as the collegial product in Brown $\%$. Dd. of Educ., as he told Senator Ervin. Hearings Before the Senate Judiciary Comm., Subcomm. on Separa. tion of Powers, 90th Cong., lst Sess., at 25 (1967). The professors paradigmatic justice, Felix Frankfurter, could hardly have thought othervise, although in the days of Holmes and Brandeis the practice was different. And the chairman agreed that "it is better to have dissenting opinions or concurring opinions beause you might find in one of them an intellectually satisfying reason for the majority opinion which docs not appear in the majority opinion, whereas if you write the opinion you try 10 reconcile views and to keep anybody from writing a dissent." Id. at 28.

The view that institutional doctrine comes too high at the price of rule by the lowest common denominator, of suffocation by mediocrity, is one that can unite partisans of Justices Frankfurter and Jackson, Black and Douglas, and the Senator from Porth Carolina. But when criticism of the quality of the justices efforts to produce opinions for the Court concedes that the alternative is more divergent individual explanations. the criticism loses a bit of its force. The desirability of unsatisfying bue citable opinions for the Court, as compared with doctrinally superior but unathoritative individual ones, must seem a mere professional preoccupation with how things are done, irrclevant to the substance of what is done. 


\section{Critical Myopia}

The fixed focus of constitutional scholarship on the United States Supreme Court is too narrow in ways that distort our view both of the judicial role and of constitutional law. It neglects the lower courts and the other institutions of government to whom constitutional lawstate as well as federal-is addressed in the first instance and by whom it must be applied, with or without elucidation by the Supreme Court.

A wider view of the constitutional system would, for example, place in perspective the traditional agonizing over the "undemocratic" character of judicial power and the Supreme Court's supposedly anomalous role in the national political structure. ${ }^{67}$ Throughout the states it is taken for granted that large areas of lawmaking are left to the courts. When a state court alters the law of products liability, abolishes sovereign or charitable tort immunity, redefines the insanity defense, or restricts the range of self-exculpation in contracts of adhesion, its action is rarely attacked as "undemocratic." Nor is this judicial role peculiar to matters of common law subject to legislative reversal. The accepted dominance of courts in state law extends to their "anti-majoritarian" role in review of their coordinate political branches in state and local governments. Yet neither judges nor critics seem concerned that state courts should fear for their own institutional survival. Nor is it seriously argued that the accepted judicial dominance in the state is legitimated by the fact that, unlike the federal judiciary, state judges are subject to periodic election.

Similarly, there are hardly any state analogues to the self-imposed constraints on justiciability, "political questions," and the like that occupy students of the Supreme Court. State courts settle contests over public offices, pass on the propriety of proposed public expenditures and even of proposed constitutional amendments, often at the suit of mere "taxpayers." The "legalitarian" urge toward judicialization that Professor Bickel deplores ${ }^{68}$ seems to have been taken for granted at the state level long before the Warren Court as a desired safeguard against slipshod government.

Nor do the holdings of state courts simply deal with less important or less controversial matters than those of the Supreme Court. In half the states, for instance, judges were enforcing the exclusion of illegally seized evidence before the Supreme Court imposed it on the other half. ${ }^{68}$ State courts were deep in controversy over the position of re-

67. IdeA of Progress 112; Politics 204.

68. IDEA OF ProGress 103-05, 115.

69. See Elkins v. United States, 364 U.S. 206, 224-32 (1960). 
ligion in education long before it became a federal issuc; some have remained so since. ${ }^{70}$ In California, the Supreme Court anticipated federal constitutional protection for racially mixed marriages by nineteen years, invalidated the most bitterly debated popular initiative of modern times, began a revolution in the historic assumptions of local school financing, and decreed an end to the death penalty which for decades had been a subject of political debate. ${ }^{71}$ And on the original battleground of the revolt against judicial supremacy-the bold reversals of "unreasonable" legislative regulation of economic affairs-many state courts have simply refused to follow the Supreme Court's withdrawal of review of this area. ${ }^{72}$

A perspective on constitutional law which considers other courts would avoid the common misconception that only the U.S. Supreme Court renders constitutional judgments. Even the generally informed public probably believes that the disputed constitutional authority for American military operations in Viet Nam has not been adjudicated, since the decisions on its justiciability and on the sufficiency of congressional involvement have come from the Courts of Appeals, not the Supreme Court. ${ }^{73}$ A similar identification of consti-

70. See, e.g., Visser v. Nooksack Valley School Dist., No. 506, 33 Wash. 2d 699, 207 P.2d 198 (1949) (bus rides); State ex rel. Clithero v. Showalter, 159 Wash. 519, 293 P. 1000 (1930) (Bible study in public schools); State ex rel. Reynolus v. Nusbaum, 17 W'is. 2d 148 , 115 N.W.2d 761 (1962) (bus rides to parochial schools), discussed in W. KATz, RELIGION AND AMERICAN CoNstrTUtIoNs 36-38, 67-69 (1964); State cx rel. W'ciss v. Dist. Bu.. 76 Wis. 177, 44 N.W. 967 (1890) (Bible reading in public schools); Dickman v. Schaol Dist. No. 62C, Oregon City, 366 P.2d 533 (1961) (textbooks). A number of older state cases are cited in Cushman, Public Support of Religious Education in American Constitulional Law, 45 ILL. L. REv. 333 (1950).

71. Perez v. Lippold, 32 Cal. 2d 711, 198 P.2d 17 (1948); cf. l'cople v. Anderson, 6 Cal. 3d 628, 493 P.2d 880 (1972), modification of opinion on denial of petition for rev'g, 6 Cal. 3d 804a - P.2d - (1972); Serrano v. Priest, 5 Cal. 3d 584, 487 P.2d 1241 (1971); Loving v. Virginia, 388 U.S. 1 (1967); Reitman v. Mlulkey, 64 Cal. 2d 529, 413 1.2d 825 (1960). The Anderson decision, cited above, drove the state attorney general to seck certiorari on the ground that the court's assumption of legislative power denies the people of California a republican form of government, petition for certiorari, California v. Anderson, p. 16. cert. denied - Cal. 3d - - P.2d - (1972). According to press reports, the death penalty decision brought an unprecedented flood of adverse mail to the court and the governor's office. Eugene Register-Guard, Mar. 30. 1972, at 11A. See also Wright, The Role of the Judiciary from Marbury $v$. Madison, 60 CALIf. L. REv. 1262 (1972).

72. See, e.g., People v. Instantwhip Denver, Inc., 57 Colo. 817, 490 1.2d 940 (1971), invalidating filled-milk laws in express rejection of Carolene l'roulucts Co. v. United States, 323 U.S. 18 (1944); and United States v. Carolene Products Co., 304 U.S. 144 (1938); Sun Ray Drive-In Dairy Inc. v. Trenhaile, 91 Idaho 308,486 p.2d 1021 (1971); Heimgaertner v. Benjamin Electric Mfg. Co., 6 Ill. 2d 152, 128 N.E.2d 691 (1955), refusing to follow Day-Brite Lighting, Inc. v. Missouri, 342 U.S. 421 (1952); Hetherington, State Economic Regulation and Substantive Due Process of Law, 53 Nw. U.L. REv. 13, 226 (1958).

73. Orlando v. Laird, 443 F.2d 1039 (1971); Berk v. Laird, 429 F.2d 302 (1970). Three months after the later decision, Professor Bickel was telling the Senate Comm. on Foreign Relations that "the issue of the constitutionality of the Victnam War -. properly enough, in my view, the courts have not adjudicated, and should not," 
tutional law with the Supreme Court lends political plausibility to the recurring attempts to overcome unpopular decisions by bills to with draw their subject matter from jurisdiction of the Supreme Court or of all federal courts. Of course even with jurisdiction removed, government at all levels would remain obliged to follow the Constitution with respect to reapportionment, school busing, school prayers, congressional contempt citations, or whatever fashionable issue might be withdrawn from the Supreme Court, and those courts retaining jurisdiction would be obliged to apply the Constitution, although they would have no way to settle inevitable divergences. But the recurring notion to withdraw jurisdiction in controversial areas would have no political appeal if the public and its representatives did not share the common identification of constitutional norm and Supreme Court review-the assumption that, freed from the Court's review, public officials and state courts would consider themselves freed also from the Court's last specification of the norm.

In the context of judicial review itself, a broader perspective on the logic of constitutional structure and premises would compel attention to state constitutional guarantees. As obligations upon state and local government, they antedate not only the Warren era but, for most states, the Fourteenth Amendment. They do not always have the same meaning, historically, as the federal text; yet they are rarely elucidated by courts, and are commonly appended as afterthoughts to federal citations if mentioned at all. How can a court find that state or local government has violated a federal guarantee, applied through the Fourteenth Amendment, but not mention the same guarantee in the state's bill of rights? Alternatively, when a court finds and corrects a violation of a state guarantee, how can it simultaneously find that the state has failed its federally imposed duty to provide due process or equal pro. tection? That such questions are more than academic is illustrated by the California Supreme Court's alternating use of state and federal clauses for its recent innovations, as well as by the implications for state constitutional guarantees in the Nixon Court's possible retreat from the exclusionary rules or other extensions of federal rights. ${ }^{74}$

without referring to above cited judicial rejections of the government's claim that the constitutionality of the President's actions was wholly unjusticiable. Hearings on IFar Powers Legislation Before the Senate Comm. on Foreign Relations, 92d Cong., 1st Sess. $552(1971)$.

74. I have discussed the foregoing questions, here compressed into rather bald statc. ments, in Linde, "Clear and Present Danger" Reexamined: Dissonance in the Branden. burg Concerto, 22 StAN. L. REv. 1163 (1970); Linde, Without "Due Process"-Unconstillı. tional Law in Oregon, 49 Oregon L. Rev. 125 (1970). The California Supreme Court's invalidation of the death penalty was based on an interpretation of the statc con. 
In still another way a critical focus wide enough to encompass state courts and other branches of government is essential to constitutional law, for it is there that Supreme Court doctrines, premises, and techniques are made operational. It would seem the essence of realism to trace a given holding or explanation in practice, through scores of briefs, opinions of state courts or prosecutor's instructions to police. Ad hoc Supreme Court decisions of "small compass" may permit resolution of a single difficult and unusual case; but when the constitutional issue concerns a common pattern recurring in scores, hundreds, or thousands of situations, there is a need for as much decisiveness and precision of doctrine as possible.

Finally, a wider focus would not neglect the role of constitutional norms in governmental institutions apart from the courts. An understanding that it is not only possible but obligatory for government to act pursuant to its constitution-an understanding of what is premise and what is consequence in judicial review-should inform not only the work of legal advisors at all levels of government but also shape the judicial articulation of constitutional norms.

\section{III}

What must ultimately be reconsidered in both criticism and adjudication is the relationship between the Constitution and judicial review. Because constitutional scholarship has remained consistently preoccupied with the institutional concerns of the judicial process, it sees constitutional law as composed of questions about what judges should do, not what government should do. The effect is to treat constitutional law as a consequence of judicial review, rather than vice versa. The resulting intellectual dilemma is not resolved in the recent critiques of the Warren Court. We are endlessly reminded of the imprecise nature of the great constitutional phrases, and told that any reliance on the text is naiveté, self-delusion, or disingenuous pretense. At the same time, we are told that the "Court is the voice of the Constitution; it is not the voice of the majority," 75 and that any view of the Constitution as a "Platonic or ideal existence before the act of declara-

stitution's prohibition of "cruel or unusual punishments," and thus was subject to amendment by the people of California in the election of November, 1972. People $v$. Inderson, 6 Cal. 3d 628, 493 P.2d 880 (1972). Cf. California v. Krivda, 5 Cal. 3d 357, 486 P.2d 1262 (1972), vacated - U.S. - (1972) for determination whether decision rested on the Fourth Amendment or its California equivalent.

75. Politics 159. 
tion"70 is a "fiction" inconsistent with the "law's self-respect,"7t and an "atavistic regression." 78

In its extreme form, the notion that only an adjudication can determine the constitutional constraints on government has astounding consequences, such as Professor Kurland's criticism of Cooper $v$. Aaron. ${ }^{70}$ Because the state of Arkansas had not been a party to Brown v. Board of Education, ${ }^{80}$ Kurland concludes that the Warren Court was "carried away with its own sense of righteousness" in Cooper when it held Arkansas to the ruling in Brown as the "supreme law of the land" under Article VI. According to Kurland, only the order of the United States District Court addressed to the Little Rock schools had that status. ${ }^{81}$ But what the Supreme Court declared in Cooper to be the supreme law of the land was "the interpretation of the Fourteenth Amendment enunciated by this Court in the Brown case." 8 Surely every state officer was under an obligation to comply with the demands of the Fourteenth Amendment-an obligation derived from the Constitution, not from the action of a trial court that might have to be invoked in order to enforce it. While the content of a particular obligation under the equal protection clause might be debatable, in Little Rock in 1956 it could hardly be something other than its content in Brown.

The dilemma of the realist tradition lies in confusing a theory of critical description with a theory of judicial action. Realism sees the norm as the product of the institution. But the institution must, by the logic of its own legitimacy, see its action as the product of the norm. However useful it is to recognize that the law emerges from what judges do, it does not serve well as a source of premises for what judges should do. The premises of constitutional law, in whatever combination of historical, textual, and political analysis, are necessarily antecedent to constitutional adjudication, even when, from the perspective of a descriptive analysis, they are its result. Nor is the postulate that there is a constitutional law directly binding on government even without judicial review only a logical presupposition of judicial review itself. That postulate underlies both consensus and dispute in the great mat-

76. Great Northern Ry. v. Sunburst Oil \& Refining Co., 287 U.S. 358, 365 (1992), where Cardozo held that a state court might take that view in applying a precedent or might limit it to prospective operation.

77. Frankfurter's concurring opinion in Griffin v. Illinois, 351 U.S. 12, 26 (1956), quoted in Pourrics 190.

78. A. Bickel, The Least Dangerous Branch 74.

79. 358 U.S. 1 (1958).

80. See note 45 supra.

81. Polincs 116, 184-86.

82. 358 U.S. at 18. 
ters of constitutional practice that are not resolved in court, as it does in nations whose constitutional law does not rely on ultimate judicial authority. Thus, it is no "atavistic regression" to see the Constitution as directly obligatory on government, with judicial review as a consequence rather than as the source of obligation. Rather, to turn the logic of constitutional law "right side up" in this way might return the attention of judges and critics from the judicial function to the constitutional premises themselves.

I do not mean that such a shift of perspective will simplify issues of constitutional interpretation or the task of resolving them. Such a shift, however, would suggest a different approach and style for their resolution. While a number of constitutional provisions speak directly to courts and judicial procedures, ${ }^{83}$ many others, including those of the First and Fourteenth Amendments which cause the greatest doctrinal disputes, are addressed not to courts but to government generally. And government must try to live by them, subject to such correction as may come from judicial surveillance.

Turning the logic of judicial review right side up implies, I suggest, a principle that a judge-made rule of constitutional law must articulate criteria with which a government conscientious about its constitutional duties could know how to comply (since in retrospect it should have known) even without judicial review. If a court is to set aside an act of government on the ground that government should have obeyed the Constitution but failed, the court should elucidate the Constitution in terms that could, if heeded, make such judicial intervention theoretically unnecessary. The principle implies a First Amendment standard, for instance, that could inform lawmakers whether they had before them a bill "abridging the freedom of speech, or of the press" when they were called upon to enact it, not only a standard by which judges can subsequently refuse application of the law to the facts in a concrete case. ${ }^{84}$ Too often our Court-centered constitutional jurisprudence produces formulations, outstandingly in the new equal protection as well as in freedom of expression, that articulate no directive for government but only the balance to be struck by judges on judicial review.

The starting point of an elucidation of constitutional clauses as norms for government, not only for judges, must be that it involves

83. E.g., Article III and the warrant, double jcopardy, sclf-incrimination, fair trial, jury, bail, and penalty provisions of the Fourth, Fifth, Sixth, Seventh, and Eighth Amendents.

84. See Linde, supra note 74. 
an exposition of the Constitution. This axiom should not be obscured by dwelling on the broadly general nature of key constitutional clauses and the limits of textual interpretation, for it involves more than a matter of texts. What differentiates constitutional adjudication from its common-law analogue is not only that common-law rules are subject to subsequent political law making, as Kurland has noted, ${ }^{\text {, }}$ but also that constitutional rules are applications of prior political law making. They reflect a series of decisions concerning the organization of government, its powers, and limitations that were made by particular men at particular moments in history. Most of these provisions are neither so hopelessly vague as to allow only undisguised policy-making, nor written in the "broad, majestic language" designed to define only "a general sort of relation between the government and its citizens," which judges must endow with "purposive permanence." 80 Rather, most constitutional provisions are firmly entrenched in terms which are applied unquestioningly by government and judges alike. Other provisions, by virtue of their words, origins, or functions, obviously contemplate changing applications in step with economic and technological developments, or with changes in the relation of the individual to social agencies.

All this should hardly need stating, but for the prevalence of another view that sees constitutional clauses as merely selections of more or less suitable pegs on which judicial policy choices are hung. Nevertheless, invocation of even the broadest, most opaque constitutional texts, such as section one of the Fourteenth Amendment, necessarily attributes the asserted principle to the political act of adopting that text, in the sense that without that political act, the principle would lack its constitutional basis. Thus, throughout all disputes over competing theories of interpretation, the judicial responsibility begins and ends with determining the present scope and meaning of a decision that the nation, at an earlier time, articulated and enacted into constitutional texta different responsibility from that of explaining why society would benefit from a judicial change in the common law. In judicial review, the line between the "juridical" and the "legislative" mode ${ }^{87}$ does not

85. PoLITICs 176-77.

86. Politics 86; Wright, supra note 1 , at $784 \cdot 85,795,797$.

87. Pourtics 110. Not that a constitutional lawyer would ever adinit to be constructing rather than construing the Constitution, any more than a theologian Holy Writ. Ilicology, as a poet laureate once wrote, may lay it down as "a fundamental rule of interpretation ... that the words and phrases of scripture are to be understood in every sense of which they are susceptible; that is, that they actually signify every thing that they can possibly signify." But the lawyers carry this rulc further: "They deduce from words not only every thing that they can possibly signify, but sometimes a great deal 
run between "strict constructionists" and competing theorists of constitutional interpretation. Rather, it divides constructionists and non-constructionists, those who do and those who do not see judicial review as a task of construing the living meaning of past political decisions-a division in which the alternating libertarianism and conservatism of the late Justices Black and Harlan were on the same side.

\section{IV}

Both judges and critics best serve their common cause when their focus is on the Constitution rather than on processes and problems of judicial review. Issues of constitutional principle in the political forum need not be treated as questions of what courts have held or will hold. Since the Constitution is addressed to government, and concerns judges only as a consequence, it offers compelling arguments for laws extending equal rights, or against wiretapping or censorship, beyond the irreducible minima of judicial invalidation; the House of Representatives is constitutionally right not to enforce subpoenas for broadcasters' tapes or newsmen's sources, even when such subpoenas might be properly sustained in court.

In the development of constitutional law during the tenure of Chief Justice Warren, critical realism may observe that there was a "Warren era," but not a "Warren Court." It may observe also that intellectually coherent method and doctrine in constitutional law is an enormously demanding affair that must be sought, by those who value it, in the performance of judges individually or with a few close colleagues, but which can be expected of a Court only in the conjuncture of an able majority, with strong leadership, sharing a basic approach to a manageable number of recurrent problems. Finally, critical realism may take note when asserted factual or historical premises in judicial reasoning are not in accord with reality.

But beyond this obligation to present and to historic facts, "realism" in judicial action is a demand, not of scholarship, but of a particular preference among ideologies of judicial review. Constitutional adjudication does not derive, from a realistic theory of laws, an overriding special obligation to pursue pragmatic "success," either for a constitutional rule or for the judicial institution. Indeed, realism may observe that those decisions of the Warren years that candidly attempted

more; and sometimes they make them bear a signification preciscly the opposite to what they were intended to express." Wright, supra note 1 , at 779,785 , quoting Southey, Law From Lay Classics, 12 ILL. L. Rev. 408,409 (1918). 
pragmatic justifications were not notably more "successful" than others resting only on assertions of chosen constitutional principle.

The Supreme Court will survive the dangers perceived with such deep pessimism by the Holmes and Cooley lecturers at the end of the Warren era; survive them more readily, I believe, the more it concentrates on the ongoing exposition of the Constitution rather than on its own institutional survival and success. It is not paradoxical that the Court may lose the public's confidence in its anti-majoritarian "elitist" role, as Kurland feared, ${ }^{88}$ precisely to the extent that it presents its rulings as the diagnosis of and prescription for contemporary social problems rather than as the most serious inquiry into historic constitutional imperatives. Nor can we realistically measure the Court's "success" without taking account of those years when, against the political real. ism of Chief Justice Vinson and Justice Frankfurter's passive virtues of institutional self-preservation, it became the role of the dissent to keep those historic imperatives in public view for another day. The whole enterprise of constitutional law rests, after all, on the premise that the nation cares about its Constitution, not about its courts. And it is this enterprise that will continue to unite judges and critics.

88. Politics 204-06. 


\section{The Yale Law Journal}

Volume 82, Number 2, December 1972

RIChaRd BLUMENTHAL Editor-in-Chief
Peter T. Grosst, Jr. Executive Editor

\author{
Curt Hessler \\ ROBERT B. REIGH \\ Gharles L. WolminanN \\ Article Editors
}

ROGER W. FONSECA Charies A. Goldmark HenRy B. HaNsManN DANIEL J. Kornstein JAY E. Powell

Note of Comment Editors

Ralph R. Arditi Michael J. BEAN JOHN R. BOLTON Colemian H. Casey Michael J. Churgin Michael M. Conway Christopher C. Curtis Rathleen M. DoggetT Peter H. Ehrenberg ROBERT W. FISHER DONAID J. FrIEDMIAN NANCY G. GaRRISON FREDERICK GoldBERG, JR.
Steven R. Gross Frederick Heller, Jr. Peter M. Hoffaran STEPHEN T. Holzer RaNDALL K.C. KAU Eugene A. Ludwig JaAIES T. MALYSIAK ROBERT B. MANN S. HardWICke MaYs, JR. NeIL H. O'DONNELL Russell K. OsGoOD
ROBERT E. GIPSON Managing Editor NaveY Y. Bekavac Book Reviews Editor
Samiel T. Perkins

LINDA L. RANDELL StEwart Rosenbluar Peter L. Rossiter Michalel L. SchleR LESLIE N. SILVERACAN Arthur J. SilversteIN PeTER WV. SLY JaAres R. SMoot MARK I. Soler ROBERT M. SUSSMAN S. MARK TULLER MARK L. WeIsSLER

Business Secretaries M. Olive Butterfield, Pakmea WmLirott

\section{Student Contributors to This Issue}

Michael J. Bean, The Legitimacy of Civil Law Reasoning in the Common Law: Justice Harlan's Contribution

Robert M. Sussman, Restructuring the Plea Bargain

Robert W. Fisher, The Applicability of the Sherman Act to Legal Practice and Other "Non-commercial" Activities

David A. Richards, Development Rights Transfer in New York Cily Peter W. Sly, In the Path of Progress: Federal Highway Relocation Assurances 